\title{
Subjective Experience and Military Masculinity at the Beginning \\ of the Long Eighteenth Century, 1688-1714
}

I.

In the twenty-five years after the 1688 Revolution, England, and then Great Britain after 1707, were involved in near continual fighting in the Nine Years' War (1688-1697) and the War of the Spanish Succession (1701-1713). The army and navy grew rapidly as the military professions began to permeate British society, which prompted, on the one hand, both resentment and antagonism and, on the other, growing acceptance. ${ }^{1}$ The army officer corps expanded fivefold from the days of Charles II and became increasingly professionalised thanks, in part, to King William's martial disposition. ${ }^{2}$ William's reluctance to appoint officers who lacked sufficient military experience augmented the number of 'professional officers' - those who relied more heavily on their commission than those who supported themselves with a combination of commissions and their estates. The army and navy became potential legitimate avenues for social mobility, typifying the rise of a 'middling sort' in Britain during the long eighteenth century.

This increased professionalisation fostered the stereotype of the brave and hardy glory-seeking British military man, which was bolstered by military literature broadcasting their patriotism. Culturally, dramatists used the character of the army officer to criticise other men they considered effeminate, such as the fop, or unpatriotic, such as the hector, while military ballads continued to advocate the worthiness of the national cause. ${ }^{3}$ However, influenced by a long-standing distrust of standing armies, the dominant contemporary stereotype among the civilian population of the British officer in the late-

\footnotetext{
I would like to thank Matthew McCormack and Jennine Hurl-Eamon for their help with this article as well as the anonymous reviewers for their helpful comments. I am also particularly indebted to Lawrence Klein and grateful for his support and comments on this work.

${ }^{1}$ John Childs, The British Army of William III, 1689-1702 (Manchester: Manchester University Press, 1987), p. 77.

2 Roger B. Manning, An Apprenticeship in Arms: The Origins of the British Army 1585-1702 (Oxford: Oxford University Press, 2006), p. 403.

3 Angela McShane, 'Recruiting Citizens for Soldiers in Seventeenth-Century English Ballads', Journal of Early Modern History 15, no. 1-2 (2011), 105-137. Hannah Smith, 'Politics, Patriotism, and Gender: The Standing Army Debate on the English Stage, circa 1689-1720', Journal of British Studies 50, no. 01 (January 2011), 48-75.
} 
seventeenth and early-eighteenth century was of unpopular martial libertinism and excessive belligerence. Technically banned from marriage, and thus denied access to one of the fundamental rites of passage into full civilian manhood, 'soldiers were simultaneously enveloped in an alternative masculinity with a distinct military character' and perceived to foster a culture of youthful irresponsibility. ${ }^{4}$ Many senior officers appeared to revel in a 'rattling, immoral lifestyle' and seemingly paid little attention to the livelihood or wellbeing of the ordinary soldier. ${ }^{5}$ Londoners often attacked men in the army because they were considered unruly and dissolute; men in the army were symbols of state intervention, with their press gangs violating widely held principles of freedom. ${ }^{6}$ Duels were thought to be frequent and drunkenness was perceived to be habitual throughout the army. These stereotypes help explain why military men were often disliked and considered to be suspicious outsiders. ${ }^{7}$

Using diaries, journals, and memoirs, and focusing on subjective experience in relation to normative expectations, this article questions such stereotypes by looking at four men in the middle ranks of the army officer corps. Such an approach demonstrates that masculine identity develops out of the process of individuals negotiating multiple prescriptions (often conditioned by conduct books at this time), everyday practice, and socio-cultural expectations. ${ }^{8}$ While prescriptive literature advocated an honourable, Christian and patriotic military masculine ideal, the everyday practice of the army fostered stereotypes of glorified aggression and impious consumption which carried their own normative weight. Within the pages of their autobiographical writings, we see men negotiating both prescriptions and stereotypes in order to construct their own identity.

\footnotetext{
${ }^{4}$ Jennine Hurl-Eamon, 'Youth in the Devil's Service, Manhood in the King's: Reaching Adulthood in the Eighteenth-Century British Army', The Journal of the History of Childhood and Youth 8, no. 2 (Spring 2015), 16390, pp. 163-6.

5 Alan Guy, 'John Churchill, Professional Soldiering, and the British Army, c1660-1760', in Marlborough: Soldier and Diplomat, eds. John B. Hattendorf, A. J. Veenendaal, and Rolof van Hövell tot Westerflier (Rotterdam: Karwansaray Publishers, 2012), 103-21, p. 120. Anthony Clayton, The British Officer: Leading the Army from 1660 to the Present (Harlow: Longman, 2007), p. 38.

6 Jennine Hurl-Eamon. Gender and Petty Violence in London, 1680-1720 (Columbus: Ohio State University Press, 2005), p. 82.

${ }^{7}$ John Childs, 'War, Crime Waves and the English Army in the Late Seventeenth Century', War \& Society 15, no. 2 (October 1997), 1-17, p. 3.

${ }^{8}$ For a discussion on the usefulness of such an approach see: Michael Roper, 'Slipping Out of View: Subjectivity and Emotion in Gender History', History Workshop Journal 59, no. 1 (Spring 2005), 57-72.
} 
The case studies examined here indicate that some contemporary stereotypes of martial libertinism and aggrandised belligerence appear to be well founded. However, the identity of individual army officers is much more complex than the notoriety of the cohort would suggest. We often see a breakdown of these stereotypes when studying individual cases. The autobiographical manuscripts examined in this article show that those who were prone to reflection and self-assessment-therefore, those who were most likely to keep an autobiographical account in the first place-did not generally subscribe to the appetitive pursuits as much as the prescriptive literature warned against and the broader cultural discourse suggested.

John Tosh has noted that, thanks to the cultural turn, the study of masculinity has become a cultural project that emphasises the study of norms and stereotypes rather than attempts to reconstruct men's lives in the past. ${ }^{9}$ Furthermore, Karen Harvey and Alexandra Shepard have suggested that the history of masculinity as a discipline needs analysis on how men related to broad culture codes in groups and cohorts. ${ }^{10}$ Grounded upon men's elucidated experience recorded in their own words, this analysis of how officers wrestled with the norms of masculinity answers such a call. Michael Mascuch observes, 'In the last decade or so the human sciences have come to appreciate the significance of narrative in general, and autobiography in particular, for the social construction of identity and meaning by human subjects. ${ }^{11}$ From this negotiation comes an awareness of these men's sense of identity. ${ }^{12}$ In her work on gender in autobiographical writing Felicity Nussbaum argues that in eighteenth-century England '...identity and character are in particular crisis, and autobiographical writing often sparks nonhegemonic concepts about the self as well as new hegemonies in formation. An analysis of eighteenth-century self-biography, then,

\footnotetext{
9 John Tosh, 'The History of Masculinity: An Outdated Concept?', in What Is Masculinity?: Historical Dynamics from Antiquity to the Contemporary World, eds. John Arnold and Sean Brady (Basingstoke: Palgrave Macmillan, 2011), 17-34, p. 22.

${ }^{10}$ Karen Harvey and Alexandra Shepard, 'What Have Historians Done with Masculinity? Reflections on Five Centuries of British History, circa 1500-1950', Journal of British Studies 44, no. 2 (April 2005), 274-80, p. 277.

${ }^{11}$ Michael Mascuch, 'Social Mobility and Middling Self-Identity: The Ethos of British Autobiographers, 16001750', Social History 20, no. 1 (January 1995), 45-61, p. 48.

${ }^{12}$ For discussions on self-identity see: Jerrold E. Seigel, The Idea of the Self: Thought and Experience in Western Europe since the Seventeenth Century (Cambridge: Cambridge University Press, 2005). Dror Wahrman, The Making of the Modern Self: Identity and Culture in Eighteenth-Century England (New Haven: Yale University Press, 2004). Michael Mascuch, Origins of the Individualist Self: Autobiography and Self-Identity in England, 1591-1791 (Cambridge: Polity, 1997).
} 
provides one pragmatic and local means of addressing these problems of identity. ${ }^{13}$ As Stuart Sherman has argued, the 'I' who writes is unavoidably different than the 'I' who performed or experienced whatever action was reported. ${ }^{14}$ Therefore, given that diaries are social texts and could be expected to be read, published or not, these ego-documents reproduce discourses of self that are inherently influenced by socio-cultural ideologies to produce a self-fashioned identity.

This article's analysis of middle-ranking army officer manuscripts is based primarily on case studies of four men who served between 1688 and 1714. The four main characters are: Lieutenant-Colonel John Blackadder (1664-1729) of the Scottish Cameronian Regiment; ${ }^{15}$ the Jacobite soldier and later antiquarian, John Stevens (1662-1726); ${ }^{16}$ Captain George Carleton (1651/2?-1730?), whose military career intermittently spanned from the Third Anglo-Dutch War to the conclusion of the War of the Spanish Succession; ${ }^{17}$ and Lieutenant-Colonel William Maxwell (1663-1752), a former medical student from Cardoness. ${ }^{18}$ John Blackadder wrote from 1700-1729, ceasing less than a year before his death. Of these four he was by far the most prolific diarist, describing his service in the army, his spiritual struggles, and his discontent with military life. For most of our period, he fought in Flanders, although some of his more poignant reflections come from his time conducting army business in London and recruiting in Scotland. Despite being much shorter, John Stevens's journal is also very much a reflection of the spiritual struggles of a devoutly religious man serving during the dynastic conflicts that marred the seventeenth and eighteenth centuries. Beginning with his journey to France to follow the fleeing King James II, Stevens's 1689-1691 journal offers the perspective of a Jacobite lieutenant during

\footnotetext{
${ }^{13}$ Felicity Nussbaum, The Autobiographical Subject: Gender and Ideology in Eighteenth-Century England (London: Johns Hopkins University Press, 1989), p. xiv.

${ }^{14}$ Stuart Sherman, 'Diary and Autobiography', in The Cambridge History of English Literature, 1660-1780, ed. John Richetti (Cambridge: Cambridge University Press, 2005), 649-672, p. 658.

15 John Blackadder, The Life and Diary of Lieut. Col. J. Blackader, ed. Andrew Crichton (Edinburgh: H.S. Baynes, 1824). The surname 'Blackadder' is sometimes spelt 'Blackader'.

${ }^{16}$ John Stevens, The Journal of John Stevens, Containing a Brief Account of the War in Ireland, 1689-1691, ed. Robert H. Murray (Oxford: Clarendon Press, 1912).

${ }^{17}$ George Carleton, The Memoirs of Captain George Carleton, and The Life and Adventures of Mrs Christian Davies (D.A. Talboys, 1840).

${ }^{18}$ William Maxwell, One of King William's Men: Being Leaves from the Diary of Col. William Maxwell of Cardoness: 1685 to 1697, ed. H. M. B. Reid (Edinburgh: John Menzies \& Co., 1898). Reid's edited title gives Maxwell the rank of Colonel but all evidence suggests he only reached the rank of Lt. Colonel. It is possible that his diary continued but the subsequent volumes did not survive except a volume for 1711 .
} 
the Williamite War in Ireland. George Carleton's memoir, completed between 1726 and 1728 , is a reflection of a career's worth of service that ranged from serving onboard the London in 1672 to being a prisoner of war in Spain in the early eighteenth century. Lastly, William Maxwell kept a diary from 1685 to 1697. Like Blackadder, Maxwell was a deeply religious Scotch Calvinist who fought in Ireland and later Flanders. Reading voices such as these embedded in the contemporary culture allows us to determine the ways in which these individuals violated or complied with the dominant contemporary ideologies while bringing to light a multiplicity of discourses. ${ }^{19}$

Concentrating on only four individuals raises the question of typicality; using autobiographical accounts limits evidence not only to those who could write but also to those who felt like they had something to say. This can be unrepresentative of reality since autobiographers were writing-either consciously or not-for an audience, whether it be their future self, their contemporaries, or posterity. However, as Nussbaum argues, 'Diaries and journals, for example, urge readers and writers to recognize themselves in existing social relations, and to believe in a sameness that makes them like all other human beings, as well as in a difference that guarantees their individuation. They also offer a private space for experimentation, revision, and resistance to prevailing notions of identity. ${ }^{20}$ Because each personal script depends on an actual or imagined audience it must necessarily be a product of the setting of its writer. ${ }^{21}$ If viewed as a mould with inherited literary conventions shaping recorded experiences rather than a 'malleable receptacle', autobiographical writings help make connections between the personal and collective reality and suggest how individual narratives of war reflected wider class, gender, religious and occupational identities. ${ }^{22}$

When historians treat the identity of military men between 1688 and 1714, they tend to subsume it within two larger historiographical narratives. The first narrative is that

\footnotetext{
${ }^{19}$ Nussbaum, The Autobiographical Subject, p. 55.

20 Ibid., xxi.

21 Mascuch, Origins of the Individualist Self, pp. 16-18.

22 Catriona Kennedy, Narratives of the Revolutionary and Napoleonic Wars: Military and Civilian Experiences in Britain and Ireland. Basingstoke: Palgrave Macmillan, 2013), p. 32.
} 
of the Restoration-era English military. ${ }^{23}$ The Restoration era navy was quickly becoming the strongest in the world. At the same time, the Restoration English army remained relatively small and widely distrusted as the public feared a recurrence of the abuses of Charles I and the Independent religious zeal of the New Model Army. The second narrative is that of the amalgamated British army that supported growing British imperialism and intervention in European affairs. This narrative, while touching upon the decades on either side of 1700, tends to focus on later episodes, the Seven Years' War, the American Revolution, and the Napoleonic Wars. ${ }^{24}$ Little, if any, attention has been paid to the individual subjective experience of men in the military during the Nine Years' War and the War of the Spanish Succession. The notable exception is John Childs who, while focusing mostly on the socio-political side of William's army rather than gendered identity, has consistently argued that, unless drunk or provoked, soldiers were no more lawless than any other social group in what was a relatively rough and lawless age. ${ }^{25}$ It is worthwhile to bring these men farther out from the shadows because, as D.W. Jones puts it, England to that point had been a relatively small player on the Continent and the 'emergence of England as a great military power in little more than two decades following the Revolution of 1688 remains one of the most remarkable, if still insufficiently appreciated, facts of the early modern period. ${ }^{26}$

The norms associated with male settings were complex, and these norms sometimes varied among settings in ways that created contention. Therefore, negotiating masculinity in accordance with the demands of various settings could be taxing. Allowing Carleton, Maxwell, Blackadder, and Stevens to demonstrate, explain, and reflect upon individual experiences in their own words presents us with testimonies of masculinity as both a social

\footnotetext{
${ }^{23}$ For example: Alan Guy, 'John Churchill, Professional Soldiering, and the British Army'. Manning, An Apprenticeship in Arms.

${ }^{24}$ For example: Linda Colley, Britons: Forging The Nation 1707-1837 (London: Vintage, 1996). John Maurice Brereton, The British Soldier: A Social History from 1661 to the Present Day (London: Bodley Head, 1986). Clayton, The British Officer. Jennine Hurl-Eamon, Marriage and the British Army in the Long Eighteenth Century: "The Girl I Left Behind Me." (Oxford: Oxford University Press, 2014).

${ }^{25}$ Childs, 'War, Crime Waves and the English Army', p. 7.

${ }^{26}$ D.W. Jones, 'Defending the Revolution: The Economics, Logistics, and Finance of England's War Effort, 16881712' in The World of William and Mary: Anglo-Dutch Perspectives on the Revolution of 1688-89, eds. Dale Hoak and Mordechai Feingold (Stanford: Stanford University Press, 1996), 59-74, p. 59.
} 
and psychic identity, a task advocated for by Tosh nearly two decades ago. ${ }^{27}$ The subjective experience culled from these autobiographical writings applies vivid colour to the characterisation of historical military masculinities and brings life to their writers' negotiation of socio-cultural stereotypes and the normative expectations portrayed in contemporary conduct literature. While it is impossible to know how widely read conduct literature was by army officers, the gendered discourse it prescribed both reflected and informed discursive standards and expectations. To test the dissolute stereotypes of the army, this article will consider how officers negotiated three sets of normative ideals: their autobiographical writings address issues of army sociability and camaraderie, religious commitment, and public affirmation and honourable reputation, all of which often overlapped and tended to inform one another. While experience varied, it also converged. Masculinity in these diaries was proved and defined not only by performance on and off the battlefield but through interaction, primarily homosocial, with each other, foreigners, and the civilian population. By commenting on their own actions or condemning the actions of others, these diaries give us a sense of what each individual, as well as society as a whole, valued.

II.

Thanks to the so-called 'military revolution' in Europe, the public increasingly expected officers to pursue stated political or military objectives, rather than to enact traditional heroic values like chasing personal acclaim and glory. ${ }^{28}$ Military essayists in the eighteenth century progressively argued that a professional soldier's stoic self-sacrifice for others was the true form of honour. Nevertheless, whatever their prescriptions, the conduct of the officer corps was influenced to some extent by the court of public opinion and a concern with personal honour continued to be part of the language of military identity. ${ }^{29}$ Indeed, Blackadder, Carleton, Stevens, and Maxwell demonstrate that the

\footnotetext{
${ }^{27}$ John Tosh, 'What Should Historians Do with Masculinity? Reflections on Nineteenth-Century Britain', History Workshop, no. 38 (January 1994), 179-202.

${ }^{28}$ Manning, An Apprenticeship in Arms, p. 432.

${ }^{29}$ Armstrong Starkey, War in the Age of Enlightenment, 1700-1789 (Westport, Conn.: Praeger, 2003), pp. 70-1.
} 
performative aspect of military masculinity was very much alive in their pursuit of honour in battle and through reputation, display, and duelling. Notions of earning honour and glory through battlefield courage merely shifted towards doing so for the distinct purpose of king and country-at least according to the normative literature-rather than out of an abstract desire for individual military glory for its own sake. In that sense, these men did conform to the stereotype of being overtly concerned with honourable perception and their reputation for physical prowess.

When he first arrived in Dublin Stevens wrote, 'Yet it was not without some shame and trouble I entered the town afoot and all covered with dust, having lived there sometime before in esteem and with splendour, and fearing to meet with many that had formerly known me in a prosperous condition. ${ }^{30}$ Although he felt shame in his misfortune, Stevens partially reconciled this feeling by drawing upon the discourse of Catholic martyrdom and by noting that there was no 'greater glory or honour' than for others to see him as a sufferer for his religion and king, further highlighting his reconciliation of religious and martial codes of masculinity. ${ }^{31}$ Stevens' instinctual concern for his appearance highlights its importance in constructing military identity and shaping public perception, further corroborated by the pride men took in their uniform and regalia. Jennine HurlEamon argues, 'Any consideration of masculine identity in the army cannot fail to recognize the power of the uniform... Although many other issues divided the army from the populace, historians have recognized the prominent role of costume...' 32 Items of pageantry and status, such as regimental colours, were also prominent in shaping public perception and fostering a sense of collective identity within the army. Carleton touched upon the importance of regalia during the Nine Years' War when he told the story of Sir Robert Douglas who, at the expense of his life, charged into an enemy hedgerow by himself to rescue his company's colours. Alluding to the longstanding importance of battle insignia to military men, Carleton wrote, 'Thus the Scotch commander improv'd upon the Roman General; for the brave Posthumius cast his standard in the middle of the enemy for his soldiers to retrieve, but Douglas retriev'd his from the middle of the enemy, without any

\footnotetext{
${ }^{30}$ Stevens, Journal, p. 51.

${ }^{31}$ Ibid., 51.

${ }^{32}$ Hurl-Eamon, Marriage and the British Army, pp. 91-2.
} 
assistance, and cast it back to his soldiers to retain, after he had so bravely rescued it out of the hands of the enemy.'33 We see that in Carleton's estimation such a performance of bravery to protect the colours-embodying the reputation of the company-constitutes a glorious feat of arms and worthy sacrifice.

While display helped shape the performative element of military masculinity, military masculinity was ultimately proved through combat. In Soldier Heroes (1994) historian Graham Dawson writes, 'Military virtues such as aggression, strength, courage and endurance have repeatedly been defined as the natural and inherent qualities of manhood, whose apogee is attainable only in battle.'34 Blackadder, Stevens, and Carleton all keenly note moments of fierce fighting in which they are involved. For Stevens, on the losing side of the Williamite War in Ireland, moments of battlefield glory were much less frequent. After being routed at the Battle of the Boyne, Stevens recalled with shame that the defeated Jacobite army retreated in disarray until they were near Dublin before reforming in their ranks to avoid the 'shame of marching in such case through the city we not long before had filled with expectation of our actions and hopes...'35 The disarray was caused when dragoons spooked the entire Lord Grand Prior's Regiment apart from him. He lamented, "This I can affirm, having stayed in the rear till all the horse were past, and looking about I wondered what madness possessed our men to run so violently nobody pursuing them. What few men I could see I called to, no commands being of force, begging them to stand together and repair to their colours...'36 This story of personal fortitude but collective cowardice is suggestive of the importance of performance in battle that resonated throughout the autobiographical works of these officers. From his viewpoint, despite losing the field Stevens affirmed his own manhood by standing his ground and mitigating the humiliation of fleeing in fear.

Blackadder and Carleton, often on the side of victory throughout their careers, record much more laudable experiences. Carleton noted a moment when he was particularly proud of his soldierly efforts, describing Prince Vaudemont's brilliant and

\footnotetext{
${ }^{33}$ Carleton, Memoirs, pp. 32-3.

${ }^{34}$ Graham Dawson, Soldier Heroes: British Adventure, Empire and the Imagining of Masculinities (London: Routledge, 1994), p. 1.

${ }^{35}$ Stevens, Journal, 130.

${ }^{36}$ Ibid., 122.
} 
courageous tactical retreat from Villeroy. At the close of the early modern period the vast size of armies made strategy increasingly important with one pamphlet noting, 'IT is the true Judgment of Men of War, Honourable Retreats are no way inferiour to brave Charges, as having less of Fortune, more of Discipline, and as much of Valour... ${ }^{37}$ Carleton revealed, '...it was not, I confess, the least part of Satisfaction in life, that my self had a share of honour under him to bring off the Rear at that his glorious retreat at Arfeel.' ${ }^{38}$ Later in his memoirs he described his happiness following his individual effort to halt an unauthorised retreat during the 1705 Siege of Barcelona:

I never thought myself happier than in this piece of service to my country. I confess I could not but value it, as having been therein more than a little instrumental in the glorious successes which succeeded; since immediately upon this notice from me, the earl galloped up the hill, and, lighting when he came to lord Charlemont, he took his half pike out of his hand, and turning to the officers and solders, told them, if they would not face about and follow him, they should have the scandal and eternal infamy upon them of having deserted their posts, and abandoned their general. ${ }^{39}$

Like Stevens, standing fast in the face of another's unsanctioned, cowardly retreat provided a unique instance in which he could demonstrate his bravery in comparison to others.

Blackadder likewise described a moment of heated combat during the Battle of Dunkeld. He wrote, 'In this hot service we continued above three hours, the Lord wonderfully assisting our men with courage, insomuch that old soldiers, that were with us said, They never saw men fight better, for there was not the least sign of fear to be seen in any of them every one performing his part gallantly. ${ }^{40}$ However, after the Battle of Schellenberg rather than revelling in victory Blackadder ruminated on the stark reality of combat and recalled praying throughout the assault as he 'witnessed one of the hottest actions I have seen... We gained our point, and beat the enemy from their post, and yet we have no reason to boast or think highly of ourselves. The British value themselves too much, and think nothing can stand before them. We have suffered considerably on this occasion, and have no cause to be proud.' 41 When casualties were heavy, Blackadder took no pleasure in victory and revealed

${ }^{37}$ R. C. The Accomplished Commander Being Necessary Instructions for the Prudent Conduct of Officers in an Army / Written by a Person of Great Experience in Military Affairs, and Published for the Common Benefit (London: J. Taylor, 1689), p. 95

38 Carleton, Memoirs, p. 37.

${ }^{39}$ Ibid., 69.

${ }^{40}$ Blackadder, Diary, p. 48.

${ }^{41}$ Ibid., 98. 
a paradox of war by noting that this glorious victory came at a cost he mentally could not justify.

Moments of battlefield courage and valour serve as examples of how public and personal affirmation confirmed masculine behaviour. The Character of a True Protestant English Souldier (1689) describes a soldier as 'sensible of the difference between Honour and Infamy, so that the horrid apprehensions of a base Life, drives him from the Fire to the Field; where carried on by an undaunted resolution, he many times obtains at once, the Souldiers three grand Utinams, Fame, Preferment, and Victory.' 42 The editor of Maxwell's diary notes that 'his conduct was so gallant that he was promoted on the field' and later presented with a ring that contained some of King William's hair. ${ }^{43}$ Rewards for valiant service often took the form of promotion, commission, or patronage and receiving praise, bolstering one's reputation, and having honourable actions recognised was a powerful motivating factor for a man in the army. Stevens confessed, "The soldier endures the scorching heat of the summer, and piercing cold of winter in the fields, lies on the ground, suffers hunger and thirst, and daily exposes himself to all dangers that his valour may be extolled, his sufferings recorded, and his magnanimity celebrated.'44 In the late seventeenth and early eighteenth centuries, honour and reputation acted as a form of social currencythe way individuals conceived of their relationship between the public projection and private perception of their character. ${ }^{45}$ In Humane Prudence (1680), republished six times during the reigns of William and Mary and Queen Anne, William De Britaine gave advice to the man who wants to 'raise himself and fortune to grandeur': 'Be studious to preserve your Reputation; if that be once lost, you are like a Cancelled Writing, of no value; and at best, you do but survive your own Funeral; for Reputation is like a Glass, which being once cracked, will never be otherwise than crazy.'46

\footnotetext{
42 The Character of a True Protestant English Souldier; With That of a Doublet-Pinking Bully-Hec. Or, a Cowardly-Spirited Animal, Who Dares Not Venture His Life in the Service of His Country (London: E.W., 1689), p. 2. Eighteenth-Century England', Transactions of the Royal Historical Society 6, no. 6 (1996), 201-13, p. 201.

${ }^{46}$ William De Britaine, Humane Prudence, Or, The Art by Which a Man May Raise Himself and Fortune to Grandeur (London: John Lawrence, 1682), p. 21.
} 
Indeed, Carleton is pleased when he learned his soldierly exploits were enhancing his reputation. He recalled, 'Having gained some little reputation in the attack of Monjouick, this difficulty was at last to be put upon me; and as some, not my enemies, supposed, more out of envy than good will.' ${ }^{47}$ Later in the campaign, while besieging Cuenca he acted explicitly with his reputation in mind. Despite acknowledging that there was little hope of success in making a difficult cannon shot, he wrote, 'I was resolved to have one shot at that window, and make those officers about me take notice of it... So soon as the smoke of my own cannon would permit it, we could see clouds of dust issuing from out of the window, which... convinced the officers, whom I had desired to take notice of it, that I had been no bad marksman.'48

This constant awareness of reputation often led to confrontations and duels. Blackadder fought a duel in Holland when another officer took offence at his truthfulness being questioned by Blackadder and his companions. ${ }^{49}$ The offended officer's need to prove his courage and status amongst his fellows by gaining satisfaction for the insult was indicative of the code of honour among army men. For the challenged officer, as Blackadder was, participating was virtually obligatory because an officer's courage must be unquestionable. An officer who refused was 'sent to Coventry', meaning fellow officers refused to associate with him except while on duty. ${ }^{50}$ However, revisiting the location of the duel in later years, Blackadder contritely recalled:

At night I went alone to visit that spit of ground, as near as I could find it, where, twelve years ago, I committed that unhappy action: There I fell down on my knees, and prayed as I had done several times throughout the day, that God would deliver me from blood-guiltiness; that the blood of the Lamb might purify the stain, and wash away the crimson dye of the poor man's blood. ${ }^{51}$

Rather than glorify the defence of his honour, Blackadder here demonstrated the tension between his moral precepts, the prescriptive norms arguing duels are sinful, and the informal expectations of the officer cohort that expected him to duel. William Maxwell, however, successfully avoided a duel without losing his honour, or so he believed. He

${ }^{47}$ Carleton, Memoirs, p. 74.

48 Ibid., 108.

${ }^{49}$ Blackadder, Diary, p. 86.

${ }^{50}$ Robert Shoemaker, 'The Taming of the Duel: Masculinity, Honour, and Ritual Violence in London, 1660-1800', Historical Journal 45, no. 3 (2002), 525-45, p. 540.

${ }^{51}$ Blackadder, Diary, p. 86. 
thanked God that '...when exposed through the foolishness of a comrade and lightness of my own spirit to duelling, yet that the Lord (I desire to think) heard my request, by preventing the same with no less honour than if it had been done. ${ }^{52}$ Through the duel we see the interplay of competing and conflicting codes within masculine discourse, demonstrating military masculinity to be far from homogeneous. While many, particularly those in the military, saw duelling as a means to confirm their status, others believed it to be incompatible with gentility or piety. ${ }^{53}$ Believing he had escaped the near obligatory demand of an army officer to duel without harming his honour, Maxwell demonstrated that, while many of the army stereotypes concerning performance and physical courage were well founded, the stereotypes were called into question by other values: the religious norms of some army men and the growing importance of civility on public sociability.

III.

In his Select Essays (1693) William Freke advised, '...an Army ought rather to be a Body of Martyrs: Debauch'd Men are fitter for an House of Correction, than to be of an orderly and designing Body, tho' in an Army.'54 With titles such as Religio Militis, or The Moral Duty of a Soldier (1690), The Christian Soldier's Penny Bible (1693), and The Soldier's Religious Exercise (1690), the vast majority of military conduct literature, like nearly all conduct literature at this time, was religious and moralistic, often listing rules or exercises for soldiers to follow in a format resembling the Ten Commandments and touching upon aspects of military virtue and honour. Mostly written by churchmen with some connection to the army, post-Restoration military conduct literature also sought to kerb some of the potential for divisive religious zeal that had plagued the New Model army by actively avoiding doctrinal arguments and instead promoting tenets of a broad-based, moralistic spirit of faith amongst the army. Authors justified the heavy religious emphasis by pointing

\footnotetext{
${ }^{52}$ Maxwell, One of King William's Men, p. 173.

${ }^{53}$ For discussions on the ambivalent attitudes towards duelling see: Shoemaker, 'The Taming of the Duel'. Robert Shoemaker, 'Male Honour and the Decline of Public Violence in Eighteenth-Century London', Social History 26, no. 2 (May 2001), 190-208. Markku Peltonen, The Duel in Early Modern England: Civility, Politeness and Honour (Cambridge: Cambridge University Press, 2003). Jennifer A. Low, Manhood and the Duel: Masculinity in Early Modern Drama and Culture (New York: Palgrave Macmillan, 2003).

${ }^{54}$ William Freke, Select Essays Tending to the Universal Reformation of Learning: Concluded with the Art of War, or a Summary of the Martial Precepts Necessary for an Officer (London: Tho. Minors, 1693), p. 255.
} 
out that soldiers were constantly a moment away from death and must be prepared for judgement. As well as explaining a soldier's Christian duty and providing examples of prayers for a variety of specific situations, conduct literature railed against vice, debauchery, duels, and lewd conversation, all of which informed the stereotypes of army dissolution. For most men in the army, and arguably men in general, religious experience differed markedly from normative expectations, the ability to conform to these expectations, and the different cultural discourses they encountered while campaigning. While religion featured in all four autobiographical writings, it did so to varying degrees. As a Protestant in Catholic Spain Carleton was acutely aware of the religious differences between himself and the local men and women with whom he came into contact, especially during his three-year open imprisonment in La Mancha. Although he consciously identifies himself in relation to the Catholics, Carleton only referred to these differences to provide context to the foreign culture he inhabited. Unlike Maxwell who interpreted and reported most proceedings through the lens of his faith, Carleton did not portray his religious character as a notable aspect of personality that sharply defined his sense of self. Absent from his autobiography are the spiritual struggles of a man living a devout life in an increasingly public, social, and modern world, as we see in the egodocuments of Blackadder and Stevens. The writings of Blackadder, Stevens, and Maxwell are prime examples of the spiritual journals and autobiographies that became increasingly prominent amongst the military, and society in general, towards the end of the seventeenth century.

First conceptualised and defined as a genre in the late eighteenth century and retrospectively applied to the previous age, writing and reading autobiography was considered 'morally and aesthetically rewarding. ${ }^{55}$ Beginning in the seventeenth century, those who had the ability to render their spiritual experience into written form, often from written notes and memoranda, had the incentive to do so as a means of self-reflection and self-trial with the approved aim of teaching Protestant piety to their audience. ${ }^{56}$ Given the pervasiveness of religion in the works of Blackadder, Stevens, and Maxwell, as well as to a lesser extent Carleton, these ego-documents suggest that religious and militaristic

\footnotetext{
55 Nussbaum, The Autobiographical Subject, pp. 1-2.

${ }^{56}$ Mascuch, Origins of the Individualist Self, pp. 65-75.
} 
discourses often imbricated rather than competed, lending credence to Jeremy Gregory's arguments that religious objectives still smoothly meshed with a variety of other ideals of masculinity in the eighteenth century. ${ }^{57}$ Furthermore, Michael Snape has argued that the close-knit nature of regimental life and hazardous conditions probably made soldiers more rather than less receptive to religion in the eighteenth and nineteenth centuries. ${ }^{58}$

Within the discourse of the army, religion went beyond simple prescriptive ideals. Many continued to see God as directly responsible for the outcome of battles and the preservation of their life. Such a belief reflected the Providential explanation victorious generals and rulers such as William III and Oliver Cromwell continued to promote into the late seventeenth century. ${ }^{59}$ Archibald Campbell, $1^{\text {st }}$ Marquess of Argyll's Instructions to a Son, first published in 1661 and republished twice during the reign of William III, advised, 'War proceeds from the ambition and malice of men, but the success of it depends on the good will of God.' 60 Following the fierce Battle of Dunkeld, in which his regiment was outnumbered four-to-one, the deeply religious John Blackadder acknowledged as much, writing to his brother that the Lord assisted the men's courage. He recalled that once victory was secured 'our men gave a great shout, and threw their caps in the air, and then all joined in offering up praises to God a considerable time for so miraculous a victory. I must really say, The Lord's presence was most visible, strengthening us, so that none of the glory belongs to us, but to His own great name... ${ }^{61}$ Blackadder's imputation of God's presence at Dunkeld is suggestive of the Providential sense of security and courage Britons held in the face of recurrent wars as part of their self-identification as God's 'chosen people, ${ }^{62}$ Similarly, in the event of victory, the 'Christian Soldier (and all of us) should know, that when Victory is given of God, all the glory is to be given to him, as his Servants have

57 Jeremy Gregory, “Homo Religiosus': Masculinity and Religion in the Long Eighteenth Century', in English Masculinities, 1660-1800, eds. Tim Hitchcock and Michèle Cohen (London: Longman, 1999), 85-110.

${ }^{58}$ Michael Snape, The Redcoat and Religion: The Forgotten History of the British Soldier from the Age of Marlborough to the Eve of the First World War (London: Routledge, 2005), p. 241.

${ }^{59}$ Manning, An Apprenticeship in Arms, p. 413.

${ }^{60}$ Archibald Campbell, Instructions to a Son by Archibald, Late Marquis of Argyle; Written in the Time of His Confinement (London: J. Latham, 1661), p. 156.

${ }^{61}$ Blackadder, Diary, p. 48.

62 Colley, Britons, p. 30. Tony Claydon and Ian McBride, 'The Trials of the Chosen Peoples: Recent Interpretations of Protestantism and National Identity in Britain and Ireland', in Protestantism and National Identity: Britain and Ireland, c.1650-1850, eds. Tony Claydon and Ian McBride (Cambridge: Cambridge University Press, 1998), p. 11. 
done. ${ }^{63}$ William Maxwell, recalling God's role in safeguarding him throughout his service with William's troops in Scotland and Ireland, wrote of the Battle of Killiecrankie, 'He has wonderfully preserved me in the day of battle July 27 th 1689 , when much blood was shed on both sides. ${ }^{64}$ Maxwell also sought to give God the glory for the successful efforts of William's forces during the campaign in Ireland in 1691. He wrote, 'I desire to acknowledge the goodness of God to the Protestant army in Ireland this summer in their taking Athlone by storm, their fighting valiantly on the 12th of July at the battle of Aghrim and giving the Irish an entire defeat, their taking of Galloway and other forts, and now being before Limerick... ${ }^{65}$

Maxwell, along with Blackadder and Stevens, an English Catholic volunteering for the Jacobites in Ireland, all intensely scrutinised their army careers and at-times irreverent comrades through a religious frame of reference. Maxwell believed that the Protestant army had been appointed to promote Christ's interest. In his diary he proclaimed, 'Now is our Protestant army taken the fields in Ireland, to oppose the cruel and bloodthirsty Irish and those of the perfidious French nation that are lately come to their assistance. Yea, now is the time when those that are for Christ and those that are for Antichrist are opposing themselves one to another. ${ }^{, 66}$ However, Maxwell repeatedly found the moral conduct of his exalted Protestant army to be wanting. He continued:

\begin{abstract}
Alas, how sad it is to think of the mixed multitude, yea the abounding sins that are raging in these armies that are for advancing the Protestant interest. $O$ that it were my earnest work, and of all that desire to be concerned this day for advancing of Christ's bleeding Church, to be wrestling with God for all of them, both officers and soldiers, that he might purge and pardon their vile abominations, and give them zeal, courage and resolution to appear as lovers of the truths of God in the day of battle... ${ }^{67}$
\end{abstract}

Although he does not elaborate on specific activities he finds detestable, Maxwell lamented the conduct of his fellow Protestants on multiple occasions, demonstrating the tension between martial stereotypes and his personal spiritual expectations and experience. Although he was damning of their behaviour, Maxwell reconciled himself to this collective on the basis of doing the Lord's work in the fight against popery. He asked 'that the Lord

\footnotetext{
${ }^{63}$ Late Chaplain to the Army. The Soldier's Religious Exercise in the Time of War (London: Ric. Chiswell, 1690), p. 16.

${ }^{64}$ Maxwell, One of King William's Men, p. 183.

${ }^{65}$ Ibid., 174.

${ }^{66}$ Ibid., 169.

${ }^{67}$ Ibid., 169-170.
} 
would not deal with them and His Church according to their sins, but according to the equity and justice of His own cause for which they appear... ${ }^{68}$

Notwithstanding the importance placed upon civil and chaste conversation by military prescriptive literature, the blasphemous talk, the profanity of their comrades, and the frequency of swearing caused Stevens and Blackadder particular torment. Although a Catholic, the ideals by which Stevens measured himself differed little from the Protestants examined here and his journal does not speak to any specific doctrinal differences. Stevens was equally wary of vice and concerned with his comrades' sacrilegious and commonly profane behaviour. He was repentant of his own vices, often used his journal as a confessional with long passages of lucid prose reflecting upon months at a time. He recalled, 'Oaths, curses, and blasphemies were the one-half of the common familiar discourse, the other part very often containing nothing but the repetition of past enormities or the plotting and contriving of some fresh piece of extraordinary lewdness.' ${ }^{69}$ If Stevens was troubled by the nature of conversation in the army, Blackadder was positively distressed, so much so that his biographer and the compiler of his papers, Andrew Crichton, observes, 'His greatest horror was to mix in society of his profligate companions in arms, and be compelled to listen to their impure or profane conversation. ${ }^{170}$ Of Blackadder's Cameronian regiment, Trevor Royle notes, 'In essence the new regiment was as much a congregation as a fighting formation, each man carried a Bible and the instructions given them at their first muster left them all in no doubt that one of their main tasks was the protection of the Presbyterian religion. ${ }^{171}$ However, like Maxwell, Blackadder found the conduct of the Protestant army wanting. Commenting on his disappointment in the Cameronian regiment, Blackadder bemoaned, "They speak just such language as devils would do. I find this ill in our trade, that there is now so much knavery in the army, that it is a wonder how a man of a straight, generous, honest soul can live in it.'72 This concern with profanity and blasphemy also appeared prominently in prescriptive texts, such as Religio Militis, or The Moral Duty of a Soldier which instructed, 'The sin forbidden, is, Taking God's Name in vain.

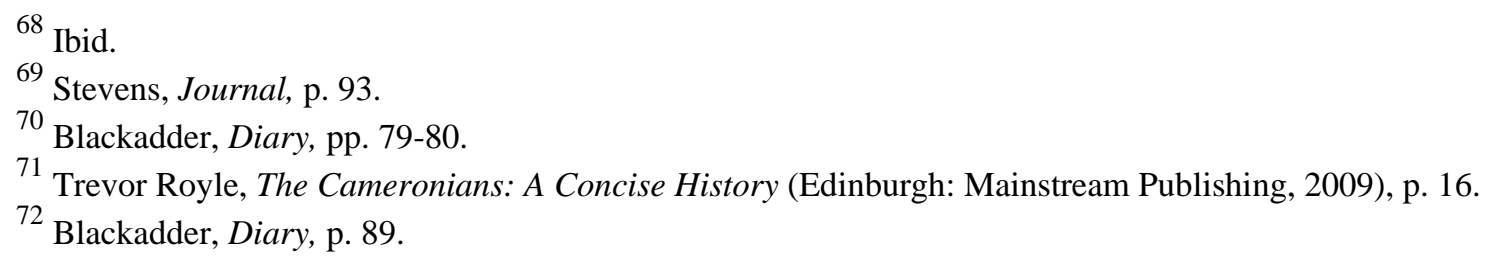


Now this may be done three way; first, by common Swearing; secondly, by taking a false Oath; or thirdly, by breaking a true one.'73 Particularly troubling to Blackadder was the disregard for the Sabbath. While marching in Germany in the spring of 1704 Blackadder recorded, 'Sabbath. Marching all day, but alas, involved in sin by company and idle discourse. A sad place to be in an army on Sabbath, where nothing is to be heard but oaths and profane language. ${ }^{74}$ Similarly, in Belgium in May 1707 he lamented, 'I was invited to dine abroad with a great man; but I shunned it, fearing temptation, company, and conversation unsuitable to a Sabbath. I wish to live tenderly and circumspectly in this army. Next day I dined, but staid too long in company.'75 Yet negotiating masculinity in accordance to the demands of various masculine spatial and institutional settings was both taxing and fluid as Blackadder shows in 1728 when, after reading through his diary, he conceded that part of the reason he was so damning of his comrades was his own stiff, unsociable nature. $^{76}$

In the introduction to Blackadder's diary, Crichton observes, 'We know how battles have been lost or won, where valiant men have fought and fallen; but the religious annals of a soldier's life, the combats he sustains with enemies within himself, and the victories to be won over the corruptions of his own heart, are of comparatively rare occurrence. ${ }^{77}$ This spiritual struggle is part of a larger discursive negotiation experienced by deeply religious men who desired to serve both their country and their God. Psychological attempts to reconcile war with Christian precepts were frequent and almost necessary. For example, the author of Religio Militis attempted to reconcile army life with Christianity: 'Not that I would seem to discourage Men from Enterprizes of Honour and Justice, for our Saviour came not to bring Peace on Earth, but a Sword, and such a Sword as is never like to be sheathed, while the World lasts, while there are Heretics and false Religions to broach, or a true Religion to defend... ${ }^{78}$ He continued, 'Yet I would have those that are to run the hazard

\footnotetext{
${ }^{73}$ C. B. Religio Militis, Or, The Moral Duty of a Soldier Shewing How He Ought to Behave Himself towards God, His King and Country (London: H.C., 1690), p. 12.

${ }^{74}$ Blackadder, Diary, p. 96.

${ }^{75}$ Ibid., 137.

${ }^{76}$ Ibid., 251.

${ }^{77}$ Ibid., p. 65.

${ }^{78}$ C. B., Religio Militis, p. 1.
} 
of the War to consider, that to die in the Field in defence of the Truth, will not do the business, unless they die in fear of God. ${ }^{79}$ The traditional bravado of the military was shaped within the context of a religiously conditioned society. As such, it was easy to depict the military as an irreligious institution considering that instances in which men conformed to normative expectations are much less noteworthy and likely to be recorded than instances in which men failed to comply with masculine ideals. Furthermore, the British soldier had a tendency to be miscast as a godless reprobate due to misgivings 'about the spiritual and moral state of young men released from the constraints of ordinary civilian life', sectarian prejudice, and deeply-rooted suspicion of a standing army. ${ }^{80}$ Nonetheless, the discourse of military masculinity was informed by literature steeped in religious sentiments and men who, on some level, engaged with notions of God frequently, if not daily.

\section{IV.}

The growing importance of sociable masculinity in the long eighteenth century is not attributable to a single cause. One could cite the decline of court culture, the growth of urban centres, particularly London, or the spread of literacy and development of a 'middling sort', amongst other factors. ${ }^{81}$ This increased emphasis on sociability was part of the spread of civility, from which a culture of politeness emerged around the beginning of the eighteenth century. ${ }^{82} \mathrm{~A}$ significant factor in this narrative of civility and politeness was the invention and spread of new, often urban, institutional and spatial social settings such as the club and coffeehouse where the culture of politeness was cultivated. This refined, developing bourgeois masculinity of the 'middling sort' tends to dominate the historiography at the beginning of the long eighteenth century. And yet, as Harvey notes:

Administratively, culturally, and militarily, Britain was forged during this period, yet there is little work on

\footnotetext{
${ }^{79}$ Ibid., p. 2.

${ }^{80}$ Snape, Redcoat and Religion, p. 236.

81 R. O. Bucholz, The Augustan Court: Queen Anne and the Decline of Court Culture (Stanford: Stanford University Press, 1993). Robert Shoemaker, The London Mob: Violence and Disorder in Eighteenth-Century England (London: Hambledon and London, 2004). Margaret Hunt, The Middling Sort: Commerce, Gender, and the Family in England, 1680-1780 (London: University of California Press, 1996).

${ }^{82}$ For a discussion on the importance of civility on masculinity see: Anthony Fletcher, Gender, Sex and Subordination in England, 1500-1800 (London: Yale University Press, 1995).
} 
the period's relationship between war and masculinity. It is clear, however, that military and naval campaigns had considerable impact on discussions of masculinity and politeness in particular. During this period, either setbacks in conflict or the cessation of victorious combat could spark debate about what kind of masculinity would most effectively serve the British nation... ${ }^{83}$

Like the urban gentleman of the rising 'middling sort', men in the army sought to confirm their membership in elite society through their conduct, money, appearance, and manners rather than the traditional landed estate and coat of arms. ${ }^{84}$ Indeed, Woodward proclaimed, 'I must say, that an Obliging and Gentile Behaviour in a Soldier, appears more Graceful than in others: The usual Military Roughness is a Shade, which renders this Civility in a Soldier the more Illustrious. So that hereby you conquer the Hearts of all People, and oblige them to serve you, which is the most noble and most effectual Way of Conquest. ${ }^{85}$ To be sure, military sociability was a setting of conflict between competing masculine codes. The proliferating prescriptive literature-advocating civil and often polite precepts that would also easily mesh with a moralistic discourse-attempted to assist men in learning proper social decorum, yet army sociability is often portrayed as a foil to the increasingly polite social world. According to the stereotype, the conduct of men in camp, aboard ship, or in town had a festive, appetitive nature with dining, drinking, lewd conversation, and gambling amongst the supposed favoured pastimes. Yet, in their efforts to condemn the attimes profligate social pursuits of their comrades, or themselves, these four officers demonstrate the discrepancy between the stereotype and individual experience.

John Stevens, fighting on the opposite side from Maxwell and Blackadder in Ireland, was very reflective about his drinking and socialising. After obtaining a commission in the Fitzjames' Regiment, Stevens spent the winter of 1689-90 encamped in Dublin with his idle regiment. It was in this idleness that men might turn to debauched entertainments of which Jacques Goussault advised, 'Avoid Idleness, as the most dangerous Evil. When the Mind is not employ'd, it becomes corrupt; but when employ'd, it becomes Spirit. ${ }^{86}$ With both English and Irish Jacobites quartered amongst regular Dubliners, the town 'seemed to be a

\footnotetext{
${ }^{83}$ Karen Harvey, 'The History of Masculinity, circa 1650-1800', Journal of British Studies 44, no. 02 (April 2005), 296-311, p. 308.

${ }^{84}$ Shoemaker, 'Taming of the Duel', p. 526.

${ }^{85}$ Josiah Woodward, The Soldier's Monitor: Being Serious Advice to Soldiers, to Behave Themselves with a Just Regard to Religion and True Manhood (London: J. Downing, 1722), p. 33.

${ }^{86}$ Jacques Goussault, Advice to Young Gentlemen, in Their Several Conditions of Life. By Way of Address from a Father to His Children (London: Tho. Leigh, 1698), p. 3.
} 
seminary of vice, an academy of luxury or rather a sink of corruption, and living emblem of Sodom...' with drink the root cause. ${ }^{87}$ Of drink and the military, The Accomplished Commander (1689) suggested, 'Drunkenness both kindles, and lays open every Vice, it removes out of the way that shame which gives impediment unto bad attempts; for where Wine gets the Mastery all the ill that before lies hidden breaks out: Drunkenness indeed rather discovers Vices, than makes them.' 88 Stevens described the indulgences to which he was witness, 'Drunkenness was so eagerly prosecuted that no liquors were strong, nor no days long enough to satiate some overhanded drunkards, whilst others, not so seasoned, by often sleeps supplied the weakness of their brain.' ${ }^{99}$ Far from an innocent observer, Stevens participated in these convivial entertainments lamenting, 'I employed myself wholly in following the court, in walking the town, in superfluous visits, in keeping company, and in what is worse in drinking and such-like idle and foolish divertisements of youth. ${ }^{90}$ Yet Stevens was contrite for his winter activities in Dublin. He wrote, 'I do not pretend to so much reservedness or zeal as wholly to condemn these pastimes, which used with moderation are in themselves innocent enough; I reprehend myself the excessive use of them, and that I was so wholly devoted to them as that they seemed to be my sole business during my stay in Dublin.' Likewise, George Carleton's memoirs highlight the problems that arise within the army when idle. With the 1705 campaign in Catalonia stalled while the council of war contemplated the siege of Barcelona, Carleton remembers, 'And now began all those difficulties to bear, which long before, by the general, had been apprehended. The troops had continued under a state of inactivity for the space of three weeks, all which was spent in perpetual contrivances and disputes amongst ourselves, not with the enemy.'91

For his part, John Blackadder was much more critical of the sociability he observed in the military. Since his diary chronicled the spiritual experiences and struggles of a devout Calvinist, Blackadder frequently moralised on the social activities of the army. Indeed, The Soldier's Monitor noted of the 'Christian Soldier', which Blackadder certainly was, that 'In his Hours of Leisure, he avoids Drinking, Gaming, and all Idleness, and either

\footnotetext{
${ }^{87}$ Stevens, Journal, p. 93.

${ }^{88}$ R. C., Accomplished Commander, p. 101.

${ }^{89}$ Stevens, Journal, p. 93.

${ }^{90}$ Ibid., 106.

${ }^{91}$ Carleton, Memoirs, p. 57.
} 
singles out such Company as is Virtuous and Agreeable, or betakes himself to some innocent Diversion, Study, or Employment. ${ }^{92}$ Blackadder was quick to condemn the actions of his comrades. For example, in August 1704 he reflected on his nearly fifteen years of service: ' $O$, I wonder at the sottish stupidity of men of our trade. They see their comrades with whom they used to drink and debauch, plucked out of the world in a moment, yet they have not so much as a thought that they have a soul, or what will become of it when they die. ${ }^{\prime 93}$ Three years later he related a personal story echoing this sentiment. He wrote, 'Hearing of a friend that died the other day at Brussels. He regretted that he had mispent and trifled away so much precious time, and that he had been so drawn away by company to tippling and drinkings. 0 that others would learn and take warning.... ${ }^{94}$ However, with temptation constant, in June 1711 near Douai Blackadder recorded, 'Dining with company. This is a great folly in the army, that when a friend dines with another, they are pressed to drink too much. I am always uneasy on these occasions. ${ }^{.95}$ From this observation, Blackadder condemned the actions of men who lacked restraint by comparing them to base animals. He wrote, 'It is really an admiration to see men endowed with reason, and with immortal souls, so degrade themselves of that dignity, and lead such poor, animal, sensual lives as they do.' ${ }^{96}$ For Blackadder, to drink to the point of drunkenness was to demonstrate a baseness more in line with a crude, barbaric form of masculinity than the refined comportment increasingly expected of the 'middling sort' at the turn of the eighteenth century.

Blackadder was also circumspect about time spent at sober entertainments and he continually complained about having to socialise when encamped with the army. While quartered in Belgium in the spring of 1706 he grumbled, 'I am too often and too long tied to companies, wearied and dissipated with dinings and diversions. I cannot live without short breathings and intervals of retirement.'97 In January 1710 while quartered in Ghent he recorded, 'This day soberly spent; but in the evening I went to hear a famous musician,

\footnotetext{
92 Woodward, Soldier's Monitor, p. 37-8.

93 Blackadder, Diary, p. 103.

${ }^{94}$ Ibid., 139.

${ }^{95}$ Ibid., 187.

96 Ibid..

${ }^{97}$ Ibid., 136.
} 
where I was kept too late, and neglected better exercise. This made me somewhat uneasy; but I bless God that he keeps me from falling often into these snares. ${ }^{98}$ His unsociable nature is best summed up when describing his time spent in London conducting military business. He wrote, 'I know I am censured by many as stingy and inconversible, because I keep so little company, and seldom mix in conversation. But when I do keep company, such as my business is with, ah! it is dear bought. A careless unthinking temper grows upon the soul... ${ }^{99}$ Maxwell also recognised the temptation bred by army sociability and idleness. However, he depicts himself as having been able to resist these temptations more so than Blackadder. At the end of the campaign season in 1691 he thanked God for preserving him from 'not only from hazard but in the time of greatest danger, not only from many snares and temptations, but when in the company of the wicked from being enticed to consent to their folly... ${ }^{100}$ Reacting against appetitive sociability, Maxwell, Blackadder, Carleton, and Stevens demonstrate that not all officers conformed to or endorsed the stereotype of martial libertinism. In the sense that these four men presented themselves as pious individuals, and considering their censure of both their own failings and other's sociable conduct, these self-writings demonstrate that negotiating masculinity in accordance with the norms of competing discourses could be taxing.

\section{V.}

No other institution illustrates the tensions between competing normative ideals and discursive models of behaviour more so than the army. Examining fear and shell shock in early twentieth-century Britain Michael Roper concludes, 'What emerges from a study of subjectivity in war memoirs is, by contrast, a view of masculinity as a process in which social scripts are negotiated, one on another, within the self. ${ }^{101}$ War autobiography in the long eighteenth century is no different in this negotiation. According to John Childs, one of the biggest problems with analysing army officers during the reign of William is the

\footnotetext{
98 Ibid., 172.

99 Ibid., 70-1.

${ }^{100}$ Maxwell, One of King William's Men, pp. 174-5.

101 Michael Roper, 'Between Manliness and Masculinity: The 'War Generation' and the Psychology of Fear in Britain, 1914-1950', Journal of British Studies 44, no. 2 (April 2005), 343-362, p. 360.
} 
difficulty of establishing a standard by which to assess them. ${ }^{102}$ Because identity is both psychic and social, subjective and contingent, I would argue that such a standard must take account of three things: normative discourse, elucidated experience, and self-analysis. Adding in the subjective and reflective experience of these four officers necessarily makes any characterisation of long eighteenth-century army masculinity less straightforward and more complex and dynamic. Yet, the testimony of these four officers frequently converges, underscoring the authority of religion, sociability, performance, and public perception to their own personal identities.

We already know that the army as an institution was mistrusted and resented by a significant portion of the population, as the Standing Army Debate of 1697-1699 attests. Yet, we should not simply reduce army masculinity to the predictably rough, sometimes corrupt, and oft-debauched contemporary public perception. By examining the individual experiences subjectively recorded by a group of men - Calvinist, a Jacobite, an army engineer, and a medical student-we can better understand the tension of mediating experience with social and cultural expectations felt by individuals and within a group. Hurl-Eamon has recently argued that, although the army culture of the long eighteenth century seems to privilege womanising, certain soldiers rejected these 'hyper-masculine' approaches and pursued courtship and marriage. ${ }^{103}$ As argued by Hurl-Eamon and demonstrated throughout this article, as a cohort some of the dissolute stereotypes appear to be well founded, but the identity of the army man on an individual level is more dynamic than the notoriety of the cohort would suggest. On an individual level we see the inadequacy of these stereotypes.

The attempt of these four officers to understand, perform, and negotiate these competing norms illustrates the tension that often existed between the expectations of a variety of masculine discourses. It is worth remembering that military masculinities are often constructed under the duress of war and through a disorienting relocation away from the familiar moral and religious mores of civilian life. Based on this evidence, I propose a partial reformulation of the narrative of the continued quasi-libertinism of the middling ranks of the army. The self-recognisance and introspection of Carleton, Blackadder,

${ }^{102}$ Childs, British Army, p. 263.
${ }^{103}$ Hurl-Eamon, Marriage and the British Army. 
Maxwell, and Stevens suggests that the tension created by their negotiation of social expectations, prescriptive ideals rendered by conduct literature, and cultural stereotypes acted as an, at least cursory, check on their behaviour. The ego-documents examined here demonstrate that soldierly identity was very fluid between the negotiation of civil sociability, the contingency of masculinity as a public performance, and principally Christian normative ideals. For these officers, this negotiation took place within a sociocultural atmosphere that already, and perhaps unfairly, anticipated bravado, aggression, and delinquency from them. 